\title{
IDENTIFIKASI POTENSI KOMODITI PERKEBUNAN RAKYAT UNGGULAN UNTUK MENDUKUNG PEMBANGUNAN EKONOMI KABUPATEN KARO
}

\section{Identification of Leading Commodities of Smallholder Plantation Potentials to Support the Economic Development of Karo District}

\author{
Rita Herawaty Bangun ${ }^{1)}$ \\ ${ }^{1)}$ Fungsional Statisitisik Badan Pusat Statistik Provinsi Sumatera Utara \\ Jalan Asrama No. 179 Medan \\ Email: rita.bangun@bps.go.id
}

Submit: 7 Juli 2020, Revised: 6 Agustus 2020, Accepted: Agustus 2020

\begin{abstract}
Potential areas need to be defined and evaluated within the context of regional development. The research aimed at evaluating and describing the product of an leading commodity of smallholder plantation. The variables used in this research were commodity production of Karo district and North Sumatera province which includes 11 commodities. The study used the location quetiont method and shift-share analysis. The location Quetiont analysis showed that clove, candlenut, coffee, coconut, sweet skin, tobacco, cocoa, betel nut, and palm are the basic commodity of the smallholder plantations in Karo district. Whereas the shift-share analysis indicated that candlenuts, coffee, coconuts, tobacco, palm oil, and rubber have a competitive advantage. These commodities are highly competitive and have the potential to advance and grow increasing the economic growth of Karo district economy.
\end{abstract}

Keywords: Location Quetiont; Smallholder Plantation and Shift-Share.

\begin{abstract}
ABSTRAK
Identifikasi dan analisis potensi wilayah perlu dilakukan dalam rangka pengembangan wilayah. Tujuan dari penelitian ini adalah untuk menganalisis dan mengidentifikasi komoditas perkebunan rakyat unggulan. Variabel yang digunakan dalam penelitian ini adalah data produksi komoditas perkebunan rakyat Kabupaten Karo dan Provinsi Sumatera Utara yang mencakup 11 komoditas. Penelitian ini menggunakan metode analisis location quetiont dan shift share. Hasil penghitungan analisis location quetiont menunjukkan bahwa cengkeh, kemiri, kopi, kelapa, kulit manis, tembakau, kakao, pinang dan aren merupakan komoditas basis perkebunan rakyat di Kabupaten Karo. Hasil analisis shift share menunjukkan bahwa kemiri, kopi, kelapa, tembakau, kelapa sawit, dan karet memiliki keunggulan kompetitif. Komoditas tersebut berdaya saing tinggi dan memiliki potensi untuk maju dan tumbuh untuk mendorong peningkatan perekonomian Kabupaten Karo.
\end{abstract}

Kata Kunci: Perkebunan Rakyat; Location Quetiont dan Shift Share. 


\section{PENDAHULUAN}

Pembangunan wilayah merupakan proses yang berkesinambungan dan bertahap dengan memanfaatkan sumber daya dan potensi yang dimiliki masing masing daerah untuk mencapai tujuan kesejahteraan masyarakat. Pendekatan pembangunan wilayah dapat dilakukan berdasarkan potensinya. Kebijakan pembangunan terkait dengan pembangunan wilayah tidak dapat dilihat secara umum tanpa melihat potensi keragaman komoditas, namun harus secara spesifik wilayah supaya program tersebut dapat dilaksanakan dengan baik, tepat sasaran dan nyata (Wang et al., 2019; Zhou et al., 2020; Aboal et al., 2020). Perencanaan pembangunan dimulai dengan menganalisis kondisi wilayah, potensi unggulan wilayah dan permasalahan yang ada di wilayah tersebut yang selanjutnya dapat digunakan sebagai dasar pertimbangan dalam menentukan strategi pengembangan wilayah. Perencanaan pembangunan yang baik sangat diperlukan ketersediaan informasi dan data tentang potensi sumber daya alam dan persebarannya sehingga dapat mendukung perencanaan pembangunan daerah (Setianto, 2014; Momm and Jöns, 2020; Jolly et al., 2020).

Identifikasi potensi kegiatan ekonomi daerah perlu untuk memperhatikan dua faktor utama yaitu sektor ekonomi yang unggul atau yang mempunyai daya saing dalam periode tahun terakhir dan kemungkinan prospek sektor ekonomi di masa mendatang (Blatt and Michael, 2020; Elechalawar et al., 2020; RondónVillarreal and López, 2020). Kedua, sektor ekonomi yang potensial untuk dikembangkan dimasa mendatang walaupun pada saat ini belum mempunyai tingkat daya saing yang baik. Dengan teridentifikasikannya potensi kegiatan ekonomi daerah maka dapat disusun kebijakan pembangunan yang berlandaskan pada upaya meningkatkan pertumbuhan ekonomi (Rizani, 2017). Analisis secara keseluruhan akan mengetahui sektor basis perekonomian masa lalu dan kemudian dapat dipergunakan sebagai bahan atau dasar 119 pertimbangan dalam membuat perencanaan pembangunan secara makro yang lebih baik di masa yang akan datang (Oktavia et al., 2015; Farrokhabadi and Babaei, 2019; Girón-Rojas et al., 2020).

Komoditas unggulan adalah komoditas andalan yang memiliki posisi strategis untuk dikembangkan di suatu wilayah (Smales, 2017; Zhang et al., 2018; Parnreiter and Bernhold, 2020). Komoditas tersebut layak diusahakan karena memberikan keuntungan kepada petani baik secara biofisik, sosial dan ekonomi. Komoditas tertentu dikatakan layak secara biofisik jika komoditas tersebut diusahakan sesuai dengan zona agroekologi, layak secara sosial jika komoditas tersebut memberi peluang berusaha, bisa dilakukan dan diterima oleh masyarakat setempat sehingga berdampak pada penyerapan tenaga kerja, dan layak secara ekonomi artinya komoditas tersebut menguntungkan (Hidayah, 2010; Hatt et al., 2018; Fanchone et al., 2020).

Beberapa pendekatan dan alat analisis untuk mengidentifikasi sektor unggulan dapat dilakukan dengan analisis location quetiont dan shift share (Abidin, 2015a; Hendayana, 2003). Analisis location quetiont digunakan untuk mengidentifikasi sektor unggulan dan mengukur konsentrasi relatif atau derajat spesialisasi kegiatan ekonomi melalui pendekatan perbandingan (Hendayana, 2003). Shift share digunakan untuk menganalisis dampak pertumbuhan regional, khususnya pertumbuhan lapangan kerja, menggambarkan tren pertumbuhan historis, memperkirakan pertumbuhan regional dan menganalisis efek dari insiatif kebijakan serta mengembangkan perencanaan strategis untuk komunitas (Abidin, 2015a; Rizani, 2017).

Penelitian tentang komoditas unggulan daerah sudah banyak dilakukan, diantaranya adalah penelitian yang dilakukan oleh (Zakiah et al., 2015) yang memetakan komoditas unggulan sub sektor perkebunan di Kabupaten Aceh Selatan. Penelitian yang sama dilakukan oleh (Pakasi and Benu, 2016) yang 
menganalisis subsektor perkebunan pala di Provinsi Sulawesi Utara. (Herdhiansyah et al., 2012), (Bangun, 2017) dan (Rahman et al., 2015) juga melakukan penelitian tentang potensi komoditas perkebunan unggulan.

Kabupaten Karo adalah salah satu daerah yang terletak di Provinsi Sumatera Utara yang memiliki potensi iklim dan kondisi lahan dengan beragam karakteristik. Adanya keragaman sifat fisik lahan ini dapat dijadikan modal dasar yang dapat digunakan dalam melakukan pertimbangan dalam menentukan perwilayahan komoditas pertanian. Keragaman sifat fisik lahan akan menentukan jenis komoditas yang dapat diusahakan serta akan berpengaruh terhadap tingkat produktivitasnya. Perencanaan pembangunan pertanian yang berdasarkan perwilayahan akan dapat mengatasi terjadinya persaingan jenis antar wilayah (Setianto, 2014).

Sektor pertanian masih merupakan andalan dalam perekonomian wilayah Kabupaten Karo. Sektor ini berperan penting dalam perekonomian dan sebagai penyedia lapangan kerja bagi masyarakat di Kabupaten Karo (BPS, 2018). Perkebunan merupakan salah satu sub sektor dalam pertanian yang memberikan kontribusi dalam rangka peningkatan perekonomian wilayah. Potensi perkebunan di Kabupaten Karo cukup besar namun hasilnya belum dapat dinikmati secara maksimal oleh masyarakat karena selama ini pembangunan pertanian terkonsentrasi pada komoditas tanaman pangan. Untuk meningkatkan produksi perkebunan di wilayah ini perlu dilakukan analisis untuk melihat potensi pengembangan komoditas perkebunan sebagai dasar dalam perencanaan pembangunan pertanian yang bertujuan untuk pembangunan wilayah di Kabupaten Karo.

Berdasarkan uraian di atas maka diperlukan penelitian untuk menganalisis dan mengidentifikasi komoditas perkebunan basis yang menjadi produk unggulan Kabupaten Karo. Tujuan dari penelitian ini adalah untuk menganalisis dan mengidentifikasi komoditas perkebunan basis yang menjadi produk unggulan untuk mendukung strategi kebijakan pembangunan pertanian dalam rangka pembangunan wilayah di Kabupaten Karo.

\section{METODE PENELITIAN}

\section{Sumber Data}

Data yang digunakan dalam penelitian ini adalah data sekunder dari publikasi yang diterbitkan oleh BPS Provinsi Sumatera Utara dan BPS Kabupaten Karo. Variabel yang digunakan adalah produksi komoditas perkebunan periode Tahun 2015-2017.

\section{Metode Analisis Data}

Metode analisis kuantitatif digunakan untuk menjawab permasalahan yang telah ditetapkan. Secara umum digunakan beberapa metode analisis data, yaitu:

\section{a. Analisis Location Quetiont (LQ)}

Analisis LQ merupakan suatu alat analisis untuk menunjukkan basis ekonomi suatu wilayah terutama dari kriteria kontribusi. Alat analisis ini juga dipakai untuk mengukur konsentrasi dari suatu kegiatan (industri) dalam suatu daerah itu dengan peranan kegiatan atau industri sejenis dalam perekonomian regional atau nasional. Perhitungan basis tersebut menggunakan variabel PDRB wilayah atas suatu kegiatan dalam struktur wilayah .

Secara matematis formula LQ adalah sebagai berikut (Bangun, 2018; Lee and Gordon, 2005; Leeuwen and Földvári, 2016):

$$
L Q_{i}=\frac{Y_{i j} / Y_{j}}{Y_{i} / Y}
$$

Keterangan :

$\mathrm{LQ}_{\mathrm{i}}$ : Indeks Location Quetiont

$\mathrm{Y}_{\mathrm{ij}}$ : Produksi komoditas perkebunan rakyat i di Kabupaten Karo

$\mathrm{Y}_{\mathrm{j}} \quad$ : Total produksi komoditas rakyat perkebunan Kabupaten Karo 
$\mathrm{Y}_{\mathrm{i}}$ : Produksi komoditas perkebunan rakyat i di Provinsi Sumatera Utara

Y : Total produksi komoditas perkebunan rakyat Provinsi Sumatera Utara

Persamaan tersebut diatas terdapat 3 (tiga) kategori hasil perhitungan LQ dalam perekonomian daerah yaitu (Hendayana, 2003):

- Jika nilai LQ > 1 artinya komoditas perkebunan yang bersangkutan di wilayah studi lebih berspesialisasi dibandingkan dengan wilayah referensi. Artinya sektor tersebut dalam perekonomian daerah di wilayah studi memiliki keunggulan komparatif dan dikategorikan sebagai komoditas basis/unggulan.

- Jika nilai LQ = 1 artinya komoditas perkebunan yang bersangkutan baik di wilayah studi maupun di wilayah referensi memiliki peningkatan.

- Jika nilai LQ $<1$ artinya komoditas perkebunan yang bersangkutan di wilayah studi kurang berspesialisasi dibandingkan dengan wilayah referensi. Sektor tersebut dikategorikan sebagai komoditas non basis/unggulan.

b. Analisis shift share

Analisis shift share digunakan untuk melihat potensi ekonomi suatu wilayah. Metode shift share bertujuan untuk menentukan kinerja atau produktivitas kinerja perekonomian daerah dengan membandingkan dengan daerah yang lebih besar (baik regional maupun nasional) (Abidin, 2015a; Puspitawati, 2013; Ratnasari, 2014). Metode shift share memiliki analisis yang lebih tajam bila dibandingkan dengan analisis location quotient (LQ) karena memberikan penjelasan secara terperinci penyebab perubahan atas beberapa variabel.

Lebih lanjut (Abidin, 2015b) menjelaskan bahwa ada beberapa metode penghitungan shift share namun yang paling umum digunakan adalah penghitungan shift share dengan pendekatan klasik. Disamping mudah dan sederhana, pendekatan ini cukup memberikan hasil yang cukup valid untuk analisis perkembangan ekonomi 121 suatu wilayah yang kecil. Pendekatan ini menjadikan pertumbuhan sebagai perubahan suatu variabel di suatu wilayah kota/kabupaten (misalnya: PDRB, nilai tambah, pendapatan atau output) selama kurun waktu tertentu, sedangkan pengaruh-pengaruh yang terjadi antara lain pertumbuhan nasional, pertumbuhan proporsional dan keunggulan kompetitif. Pengaruh pertumbuhan nasional disebut pengaruh pangsa (share), pengaruh pertumbuhan proporsional disebut proportional shift dan pengaruh keunggulan kompetitif dinamakan differential shift atau regional share (Abidin, 2015a; Ratnasari, 2014).

Bentuk umum persamaan dari analisis shift share dan komponenkomponennya adalah (Knudsen, 2000):

$\Delta E_{\mathrm{r}},=E_{\mathrm{r}},-\mathrm{E}_{r, \mathrm{i}, \mathrm{t}-\mathrm{n}}$

Artinya pertambahan lapangan usaha dalam skala regional sektor i adalah jumlah lapangan usaha sektor i pada tahun akhir (t) dikurangkan dengan lapangan usaha sektor i pada tahun awal (t-n). Pertambahan lapangan kerja regional sektor i ini dapat diperinci atas pengaruh dari national share, proportional shift, dan differential shift.

$\Delta E \mathrm{r},,=(N i+P i+D i)$.

$N i,=E,-n(\mathrm{EN}, \mathrm{t} / \mathrm{EN}, \mathrm{t}-\mathrm{n})-\mathrm{Er}, \mathrm{i}, \mathrm{t}-\mathrm{n}$

$P i,=\{(E N,, / E N, i, t-n)-(E N, t / E N, t-n)\} \times$

$E r, i, t-n$

$D i, t=\{E i, r, t-(E N, i, t / E N, i, t-n) E r, i, t-n\} .(6)$

Keterangan :

$\Delta$ : Perubahan,tahun akhir (tahun $\mathrm{t}$ )

dikurangi dengan tahun awal (tahun $\mathrm{t}-\mathrm{n}$ )

$\mathrm{N}$ : Provinsi Sumatera Utara

$\mathrm{r}$ : Karo

E : Total Produksi Perkebunan (Ton)

i : Komoditas perkebunan

$\mathrm{t}$ : Tahun

t-n : Tahun awal

$\mathrm{Ni}$ : National share

$P i$ : Proportional shift

Di : Differential shift

Pengukuran dari analisis shift share:

a. Jika $N i$ bernilai positif, maka pertumbuhan komoditas i di Kabupaten Karo lebih cepat dibandingkan dengan pertumbuhan komoditas yang sama di Provinsi Sumatera Utara. Apabila $\mathrm{Ni}$ 
bernilai negatif, menunjukkan bahwa pertumbuhan komoditas perkebunan i di Kabupaten Karo lebih lambat dibandingkan dengan pertumbuhan komoditas perkebunan yang sama di daerah Provinsi Sumatera Utara.

b. Proportional shift (Pi) merupakan komponen yang dipakai untuk menghasilkan besarnya shift netto bila terjadi perubahan pada produksi perkebunan yang bersangkutan. Jika $P i$ bernilai positif di Kabupaten Karo yang berspesialisasi di komoditas secara nasional akan tumbuh lebih cepat dan jika negatif bila daerah berspesialisasi pada komoditas akan tumbuh lebih lambat.

c. Di menunjukkan differential shift yang dipakai untuk mengukur besarnya shift netto yang diakibatkan komoditas perkebunan tertentu yang lebih cepat atau lambat pertumbuhannya di daerah yang bersangkutan karena faktor lokasional seperti melimpahnya sumber daya dan mengukur keunggulan kompetitif kmoditas di daerah tersebut. $D i$ bernilai positif pada komoditas yang memiliki keunggulan kompetitif dan $D i$ bernilai negatif pada komoditas perkebunan yang tidak memiliki keunggulan kompetitif.

\section{HASIL DAN PEMBAHASAN}

\section{Perkembangan Produksi dan Luas Tanam Perkebunan Kabupaten Karo}

Produksi komoditas perkebunan rakyat di Kabupaten Karo selama kurun waktu Tahun 2015-2017 terus menunjukkan peningkatan. Produksi komoditas perkebunan rakyat pada Tahun 2015 sebesar 16.088.55 ton meningkat sebesar $2.108,4$ ton menjadi 18.196,95 ton pada Tahun 2016, dan kembali meningkat sebesar 2.415,42 di Tahun 2017 (Gambar 1). Luas tanaman komoditas perkebunan rakyat di Kabupaten Karo selama periode waktu Tahun 20152015 juga menunjukkan pola yang sama dengan produksi komoditas perkebunan. Luas tanaman komoditas perkebunan rakyat selama tiga tahun terakhir cenderung meningkat. Luas tanaman perkebunan rakyat pada Tahun 2015 yaitu 17.790 hektar, meningkat menjadi $18.130,62$ hektar pada
Tahun 2016 dan pada Tahun 2017 kembali meningkat sebesar 295,38 hektar (Gambar 2).

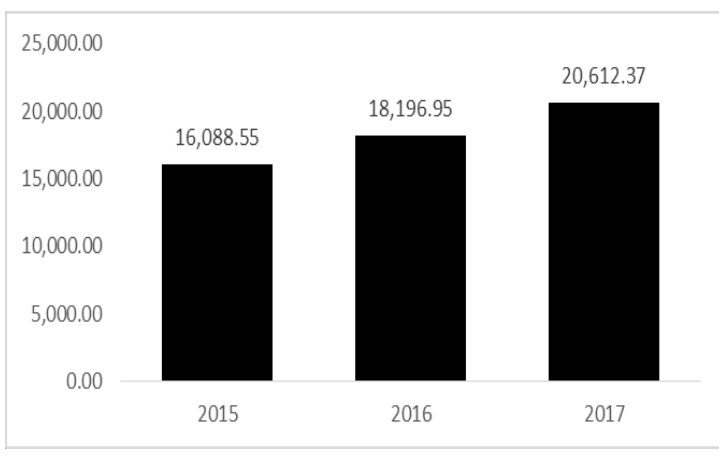

Gambar 1. Perkembangan Produksi Perkebunan Kabupaten Karo Tahun 2015-2017(Ton)

Sumber: BPS, 2018

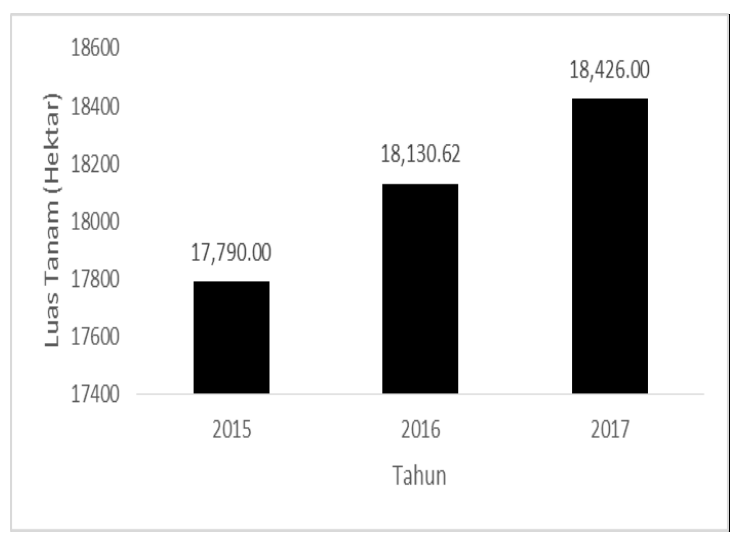

Gambar 2. Perkembangan Luas Tanaman Perkebunan Kabupaten Karo Tahun 2015-2017(Hektar)

Sumber: BPS, 2018

Kopi merupakan komoditas utama perkebunan yang diusahakan di Kabupaten Karo selama periode Tahun 2015-2017 diikuti komoditas kelapa sawit dan coklat (Gambar 3). Produksi kopi mencapai $8.777,02$ ton dengan luas tanaman 8.378 hektar. Kopi menyumbang 42,58 persen terhadap total produksi perkebunan pada Tahun 2017. Kopi merupakan salah satu komoditas perkebunan yang menjadi komoditas ekpor di Indonesia karena mempunyai nilai ekonomis yang relatif tinggi di pasaran dunia (Supriyadi et al., 
2014). Hal ini menjadi salah satu faktor pendorong tingginya minat masyarakat di Kabupaten Karo untuk mengusahakan komoditas kopi yang mendorong laju perekonomian masyarakat khususnya di perdesaan.

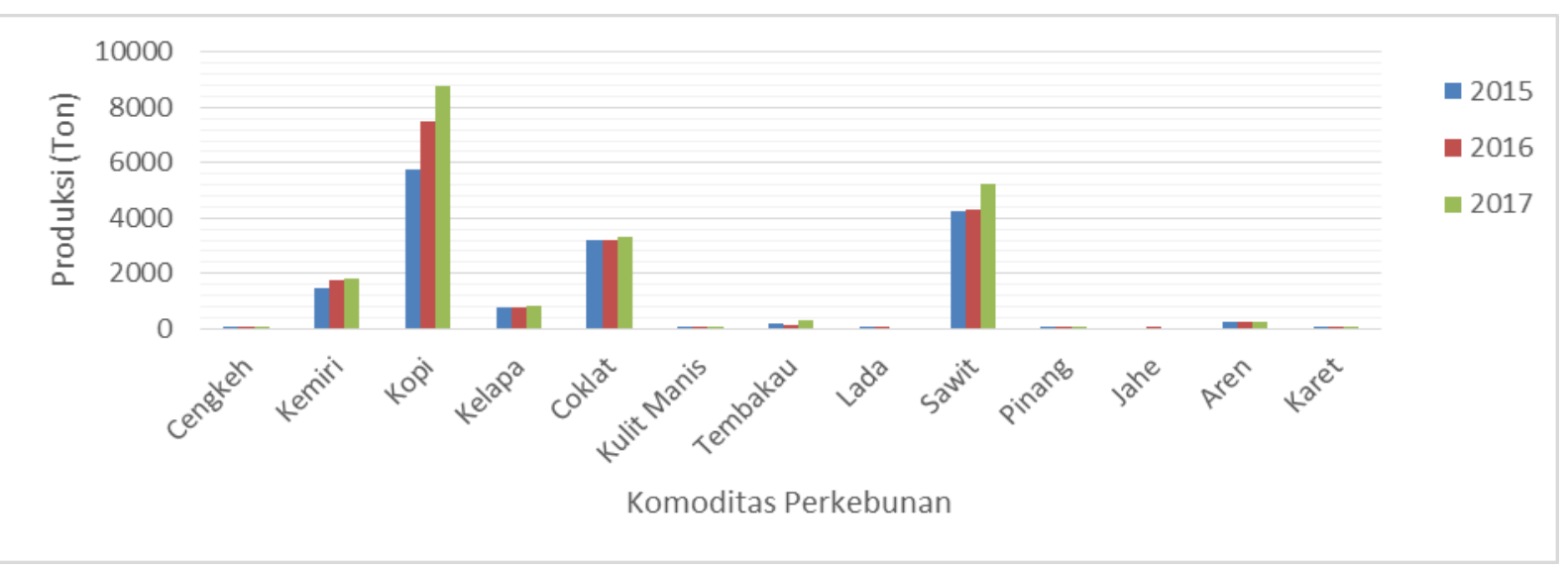

Gambar 3. Produksi Perkebunan menurut Komoditasnya di Kabupaten Karo Tahun 2015-2017 (Ton)

Sumber: BPS, 2018

\section{Analisis LQ}

Analisis LQ digunakan untuk mengetahui komoditas yang termasuk ke dalam komoditas basis atau berpotensi ekspor dankomoditas nonbasis. Apabila hasil perhitungannya menunjukkan angka lebih dari satu (LQ > 1) berarti komoditas tersebut merupakan komoditas basis. Sebaliknya apabila hasilnya menunjukkan angka kurang dari satu (LQ < 1) berarti komoditas tersebut bukan komoditas basis. Hasil penghitungan LQ komoditas perkebunan di Kabupaten Karo dapat dilihat pada tabel 1 .

Berdasarkan hasil analisis LQ komoditas perkebunan yang diusahakan di Kabupaten Karo yang merupakan komoditas basis/unggulan adalah cengkeh, kemiri, kopi, kelapa, kulit manis, tembakau, kakao, pinang dan aren. Sembilan komoditas ini sebagai komoditas basis/unggulan karena memiliki nilai LQ lebih besar dari 1. Komoditas tembakau memiliki nilai LQ terbesar yaitu 58,98 diikuti kemiri dan kopi. Tembakau merupakan salah satu tanaman yang dibutuhkan sebagai bahan baku penunjang perekonomian rakyat sebagai produksi rokok. Tanaman ini memiliki harga jual yang cukup tinggi sehingga bisa meningkatkan perekonomian petani untuk menopang kebutuhan sehari-hari (Fauziyah et al., 2010). Tembakau merupakan salah satu komoditas perkebunan yang memiliki beneficiary tertinggi dibandingkan komoditas perkebunan lainnya. Tembakau masih merupakan komoditas perkebunan andalan karena posisi tawar tembakau Indonesia di perdagangan internasional masih cukup kuat dan diminati (Tarigan et al., 2013)

Sembilan komoditas perkebunan basis/unggulan ini menjadi prioritas pengembangan karena memiliki keunggulan komparatif dan sebagai salah satu sumber pertumbuhan ekonomi daerah. Produksi sembilan komoditas perkebunan basis ini sudah mampu untuk memenuhi kebutuhan daerah Kabupaten Karo dan berpeluang untuk diekspor ke daerah lain.

Kelapa sawit dan karet merupakan komoditas perkebunan yang bukan basis/bukan unggulan, karena memiliki nilai LQ di bawah 1. Produksi kelapa sawit dan karet belum mampu memuhi kebutuhan wilayah Kabupaten Karo sehingga ada kecenderungan melakukan impor dari daerah lain. Komoditas kelapa sawit dan 
karet tetap harus mendapatkan perhatian dari pemerintah daerah Kabupaten Karo karena pertumbuhan komoditas bukan basis tersebut akan mendukung pertumbuhan komoditas basis/unggulan.

Pemerintah daerah Kabupaten Karo perlu untuk membuat roadmap pengembangan dan kebijakan yang mendukung pengembangan komoditas perkebunan basis/unggulan. Peluang peningkatan produksi komoditas perkebunan basis/unggulan masih cukup besar karena didukung potensi wilayah dan iklim selain itu peluang pasar untuk komoditas perkebunan basis/unggulan masih cukup besar.

\section{Analisis Shift Share}

Analisis shift share menjelaskan pengaruh komoditas perkebunan pada wilayah yang lebih tinggi (Provinsi Sumatera Utara) terhadap komoditas perkebunan di Kabupaten Karo. Pengaruh komponen pertumbuhan produksi (Ni) menunjukkan seberapa besar pertumbuhan komoditas perkebunan di Provinsi Sumatera Utara berpengaruh (positif atau negatif) terhadap pertumbuhan produksi komoditas perkebunan di Kabupaten Karo (Tabel 2).
Nilai regional share terbesar komoditas perkebunan di Kabupaten Karo adalah kopi diikuti kelapa sawit dan kemiri sedangkan share terkecil adalah komoditas coklat. Fenomena ini bisa dipahami bahwa saat ini kopi merupakan salah satu komoditas perkebunan yang yang potensial untuk dikembangkan karena kopi termasuk salah satu komoditi ekspor yang menjanjikan dan harga yang relatif tinggi (Ginting et al., 2017).

Hasil pengolahan komponen shift share menunjukkan bahwa selama periode waktu tahun 2015-2017, pertumbuhan komoditas kemiri, kopi, kelapa, tembakau, kelapa sawit dan aren di Kabupaten Karo lebih tinggi dibandingkan dengan pertumbuhan komoditas yang sama di Provinsi Sumatera Utara. Komoditas perkebunan lainnya yaitu cengkeh, kulit manis, coklat, pinang dan karet memiliki komponen pertumbuhan lebih rendah dibandingkan dengan pertumbuhan komoditas yang sama di Provinsi Sumatera Utara. Adanya persaingan produksi antar wilayah menjadi faktor yang mempengaruhi penurunan pertumbuhan komoditas tersebut.

Tabel 1. Hasil Penghitungan LQ Komoditas Perkebunan di Kabupaten Karo Tahun 2015-2017

\begin{tabular}{|c|c|c|c|c|c|}
\hline \multirow{2}{*}{ Komoditas } & \multicolumn{4}{|c|}{ LQ } & \multirow{2}{*}{ Kriteria } \\
\hline & 2015 & 2016 & 2017 & Rata-rata & \\
\hline (1) & (2) & (3) & (4) & (5) & (6) \\
\hline Cengkeh & 51,74 & 45,13 & 28,05 & 41,64 & Basis \\
\hline Kemiri & 49,42 & 51,85 & 46,61 & 49,29 & Basis \\
\hline Kopi & 40,20 & 46,14 & 46,55 & 44,30 & Basis \\
\hline Kelapa & 3,49 & 3,10 & 2,93 & 3,17 & Basis \\
\hline Kulit Manis & 1,37 & 1,21 & 0,97 & 1,18 & Basis \\
\hline Tembakau & 54,35 & 40,47 & 82,12 & 58,98 & Basis \\
\hline Kakao & 34,34 & 30,84 & 25,22 & 30,13 & Basis \\
\hline Kelapa Sawit & 0,32 & 0,29 & 0,30 & 0,31 & Bukan Basis \\
\hline Pinang & 2,34 & 2,05 & 1,77 & 2,05 & Basis \\
\hline Aren & 28,01 & 25,62 & 21,85 & 25,16 & Basis \\
\hline Karet & 0,10 & 0,09 & 0,08 & 0,09 & Bukan Basis \\
\hline
\end{tabular}

Sumber : Data sekunder diolah, 2019 
Tabel 2. Komponen Shift Share Komoditas Perkebunan di Kabupaten Karo tahun 2013-2017

\begin{tabular}{|c|c|c|c|}
\hline Komoditas & $\Delta \mathrm{Ei}$ & $\mathrm{Ni}$ & $\Delta \mathrm{Ei}-\mathrm{Ni}$ \\
\hline$(1)$ & $(2)$ & (3) & (4) \\
\hline Cengkeh & $-1,27$ & 3,52 & $-4,79$ \\
\hline Kemiri & 301,85 & 67,28 & 234,57 \\
\hline Kopi & 2991,16 & 261,44 & 2729,72 \\
\hline Kelapa & 38,03 & 34,19 & 3,84 \\
\hline Kulit Manis & $-1,11$ & 0,51 & $-1,62$ \\
\hline Tembakau & 111,22 & 7,43 & 103,79 \\
\hline Coklat & 99,25 & 145,12 & $-45,87$ \\
\hline Kelapa Sawit & 957,24 & 193,21 & 764,03 \\
\hline Pinang & 0 & 0,96 & $-0,96$ \\
\hline Aren & 27,68 & 10,00 & 17,68 \\
\hline Karet & 0 & 3,28 & $-3,28$ \\
\hline
\end{tabular}

Sumber data: Data sekunder diolah, 2019

Berdasarkan hasil penghitungan pertumbuhan proporsional $(\mathrm{Pi})$ pada Tabel 3, menunjukkan komoditas cengkeh, kopi, coklat, kelapa sawit, pinang dan aren memiliki nilai $\mathrm{Pi}$ positif yang artinya komoditas tersebut produksinya tumbuh lebih cepat dibandingkan dengan komoditas perkebunan lainnya di Kabupaten Karo. Hal ini menggambarkan bahwa komoditas perkebunan yang menjadi komoditas spesialisasi adalah komoditas cengkeh, kopi, coklat, kelapa sawit, pinang dan aren di Kabupaten Karo.

Tabel 3. Komponen

Pertumbuhan Proporsional (Pi) Komoditas Perkebunan di Kabupaten Karo tahun 2015-2017

\begin{tabular}{lrr}
\hline \multicolumn{1}{c}{ Komoditas } & \multicolumn{1}{c}{ Pi } & \multicolumn{1}{c}{ Kriteria } \\
\hline Cengkeh & $(2)$ & $(3)$ \\
\hline Kemiri & 33,06 & Cepat \\
\hline Kopi & $-19,07$ & Lambat \\
\hline Kelapa & 89,72 & Cepat \\
\hline Kulit Manis & $-23,81$ & Lambat \\
\hline Tembakau & $-0,12$ & Lambat \\
\hline Coklat & $-24,17$ & Lambat \\
\hline Kelapa Sawit & 293,37 & Cepat \\
\hline Pinang & 24,76 & Cepat \\
\hline Aren & 0,53 & Cepat \\
\hline Karet & 27,21 & Cepat \\
\hline
\end{tabular}

Sumber data: Data sekunder diolah, 2019
Komponen pertumbuhan diferensial (Di) digunakan untuk mengetahui daya saing komoditas perkebunan di Kabupaten Karo. Menurut (Kurniawan et al., 2017), pertumbuhan pangsa wilayah (differential shift) terjadi karena peningkatan atau penurunan output suatu wilayah yang lebih cepat/lambat dibandingkan wilayah-wilayah lain atau nasional yang ditentukan oleh keunggulan komparatif, akses ke pasar input dan output, dukungan kelembagaan, infrastruktur sosial dan ekonomi, dan kebijakan ekonomi nasional.

Komoditas perkebunan yang mempunyai nilai Differential Shift (Di) positif menunjukkan bahwa komoditas perkebunan tersebut memiliki daya saing lebih tinggi dibandingkan komoditas perkebunan lainnya di Kabupaten Karo. Sebaliknya komoditas perkebunan yang mempunyai nilai Differential Shift (Di) negatif menunjukkan bahwa komoditas perkebunan tersebut memiliki daya saing lebih rendah dibandingkan komoditas perkebunan lainnya di Kabupaten Karo.

Berdasarkan hasil penghitungan differential shift (Di) pada tabel 4, diketahui bahwa komoditas kemiri, kopi, kelapa, tembakau, kelapa sawit, dan karet memiliki nilai $D i$ positif yang menunjukkan bahwa komoditas tersebut memiliki daya saing yang tinggi dan mempunyai potensi untuk maju dan tumbuh yang mendorong 
peningkatan pertumbuhan ekonomi Kabupaten Karo.

Komoditas cengkeh, kulit manis, coklat, pinang, dan aren mempunyai daya saing yang rendah di tingkat Provinsi Sumatera Utara. Komoditas cengkeh, kulit manis, coklat, pinang, dan aren tidak memiliki prospek untuk dikembangkan karena nilai ekonomis yang rendah. Pola persaingan yang rendah pada sektor agraris dan industri pengolahan dipengaruhi oleh luas lahan dan juga akses infrastruktur (Atmaja and Mahalli, 2015) dan pergeseran aktivitas sektor pertanian ke non pertanian (Rasyid, 2016).

\section{Tabel 4. Komponen Pertumbuhan Differential (Di) Komoditas Perkebunan di Kabupaten Karo tahun 2015-2017}

\begin{tabular}{lrc}
\hline \multicolumn{1}{c}{ Komoditas } & \multicolumn{1}{c}{ Pi } & Kriteria \\
\hline Cengkeh & $(2)$ & $(3)$ \\
\hline Kemiri & $-37,85$ & Rendah \\
\hline Kopi & 253,64 & Tinggi \\
\hline Kelapa & $2.640,00$ & Tinggi \\
\hline Kulit Manis & $-1,51$ & Tinggi \\
\hline Tembakau & 127,96 & Rendah \\
\hline Coklat & $-339,23$ & Rendah \\
\hline Kelapa & & Tinggi \\
Sawit & 739,26 & \\
\hline Pinang & $-1,49$ & Rendah \\
\hline Aren & $-9,53$ & Rendah \\
\hline Karet & 4,50 & Tinggi \\
\hline
\end{tabular}

Sumber data: Data sekunder diolah, 2019

\section{KESIMPULAN}

Perkembangan produksi dan luas pertanaman komoditas perkebunan selama periode waktu tahun 2015-2017 menunjukkan peningkatan yang signifikan karena didukung oleh komoditas yang potensial. Berdasarkan hasil penghitungan analisis $L Q$, komoditas yang menjadi basis atau unggulan di Kabupaten Karo adalah cengkeh, kemiri, kopi, kelapa, kulit manis, tembakau, kakao, pinang dan aren. Komoditas tersebut merupakan komoditas prioritas untuk dikembangkan guna peningkatan pertumbuhan ekonomi serta peningkatan kesejahteraan masyarakat. Berdasarkan hasil analisis shift share komoditas yang memiliki keunggulan kompetitif yaitu kemiri, kopi, kelapa, tembakau, kelapa sawit, dan karet yang memiliki daya saing yang tinggi dan potensial untuk maju dan tumbuh yang mendorong peningkatan perekonomian Kabupaten Karo.

\section{DAFTAR PUSTAKA}

Abidin, Z., 2015a. Aplikasi Analisis Shift Share pada Transformasi Sektor Pertanian dalam Perekonomian Wilayah di Sulawesi Tenggara. Informatika Pertanian 24, 165-178.

Abidin, Z., 2015b. Aplikasi Analisis Shift Share pada Transformasi Sektor Pertanian dalam Perekonomian Wilayah di Sulawesi Tenggara. Informatika Pertanian 24, 165-178.

Aboal, D., Crespi, G., Perera, M., 2020. How effective are cluster development policies? Evidence from Uruguay. World Development Perspectives 18, 100196.

https://doi.org/10.1016/j.wdp.2020.100 196

Atmaja, H.K., Mahalli, K., 2015. Pengaruh peningkatan infrastruktur terhadap pertumbuhan ekonomi di Kota Sibolga. Jurnal Ekonomi dan keuangan 3, 350-265.

Bangun, R.H., 2018. Analisis prioritas pembangunan wilayah berdasarkan sektor produk domestik regional bruto kabupaten tapanuli tengah-sumatera utara (. Litbang Sukowati 2, 19-35.

Bangun, R.H., 2017. Kajian Potensi Perkebunan Rakyat di Provinsi Sumatera Utara Menggunakan Location Quotient dan Shift Share. Jurnal Agrica 10, 103-111. 
Blatt, S., Michael, A., 2020. Bridging the gap in identification: Sella turcica bridging as a potential positive identification factor. Forensic Imaging 21, 200384. https://doi.org/10.1016/j.fri.2020.2003 84

Elechalawar, C.K., Hossen, Md.N., McNally, L., Bhattacharya, R., Mukherjee, P., 2020. Analysing the nanoparticleprotein corona for potential molecular target identification. Journal of Controlled Release 322, 122-136. https://doi.org/10.1016/j.jconrel.2020.0 3.008

Fanchone, A., Alexandre, G., Chia, E., Diman, J.-L., Ozier-Lafontaine, H., Angeon, V., 2020. A typology to understand the diversity of strategies of implementation of agroecological practices in the French West Indies. European Journal of Agronomy 117, 126058.

https://doi.org/10.1016/j.eja.2020.1260 58

Farrokhabadi, A., Babaei, R., 2019. Development of an integrated micro macro model for anticipating matrix cracking evolution and fiber breakage in the laminated composite containing an open hole. Engineering Fracture Mechanics 211, 161-179. https://doi.org/10.1016/j.engfracmech. 2019.02.004

Fauziyah, E., Hartoyo, S., Kusnadi, N., Kuntjoro, S.U., 2010. Analisis produktivitas usahatani tembakau di kabupaten pamekasan. Jurnal Organisasi dan Managemen 6, 119132.

Ginting, A., Nainggolan, H.L., Siahaan, G., 2017. Analisis Faktor-Faktor Yang Mempengaruhi Sentra Produksi Komoditi Kopi Di Kabupaten Humbang Hasundutan. Agrisep 18, 69-79.
Girón-Rojas, C., Gil, E., Garcia-Ruiz, A., Iglesias, N., López, M., 2020. Assessment of biowaste composting process for industrial support tool development through macro data approach. Waste Management 105, 364-372.

https://doi.org/10.1016/j.wasman.2020. 02.019

Hatt, S., Boeraeve, F., Artru, S., Dufrêne, M., Francis, F., 2018. Spatial diversification of agroecosystems to enhance biological control and other regulating services: An agroecological perspective. Science of The Total Environment 621, 600-611. https://doi.org/10.1016/j.scitotenv.201 7.11.296

Hendayana, R., 2003. Aplikasi Metode Location Quotient (LQ) dalam Penentuan Komoditas Unggulan Nasional. Jurnal Informatika Pertanian $12,1-21$.

Herdhiansyah, D., Sutiarso, L., Purwadi, D., 2012. Strategi pengembangan potensi wilayah agroindustri perkebunan unggulan. Jurnal Teknik Industri 13, 201-209.

Hidayah, I., 2010. Analisis Prioritas Komoditas Unggulan Perkebunan Buru. AGRIKA 4, 1-8.

Jolly, S., Grillitsch, M., Hansen, T., 2020. Agency and actors in regional industrial path development. A framework and longitudinal analysis. Geoforum 111, 176-188. https://doi.org/10.1016/j.geoforum.202 0.02 .013

Knudsen, D.C., 2000. Shift-share analysis: Further examination of models for the description of economic change. Socio-Economic Planning Sciences 34, 177-198. 
Kurniawan, M.S., Sudarti, Arifin, Z., 2017. Analisis potensi struktur ekonomi unggulan dan daya saing sub sektor pertanian di kota batu tahun 20112015. Jurnal Ilmu Ekonomi 1, 416429.

Lee, Y., Gordon, R.H., 2005. Tax structure and economic growth. Journal of Public Economics 89, 1027-1043. https://doi.org/10.1016/j.jpubeco.2004. 07.002

Leeuwen, B. Van, Földvári, P., 2016. The Development of Inequality and Poverty in Indonesia, 1932-2008. Bulletin of Indonesian Economic Studies 52, 379-402.

Momm, C.F., Jöns, H., 2020. Decentralized concentration through cyclical events: The geographies of academic conferences in urban and regional development and planning in Brazil, 2004-2013. Geoforum 112, 104-117. https://doi.org/10.1016/j.geoforum.202 0.01 .004

Oktavia, Z., Hadi Darwanto, D., Hartono, S., 2015. Sektor Pertanian Unggulan di Sumatera Selatan. AGRARIS: Journal of Agribusiness and Rural Development Research 1, 61-69. https://doi.org/10.18196/agr.129

Pakasi, C.B.D., Benu, N.M., 2016. ANALISIS SUB-SEKTOR PERKEBUNAN PALA DI PROVINSI SULAWESI UTARA. Jurnal ASE 12, 67-76.

Parnreiter, C., Bernhold, C., 2020. Global Commodity Chains, in: International Encyclopedia of Human Geography. Elsevier, pp. 169-176. https://doi.org/10.1016/B978-0-08102295-5.10071-X

Puspitawati, L.T., 2013. Analisis perbandingan faktor-faktor penyebab ketimpangan pembangunan antar kabupaten/kota di kawasan kedungsapur. Economic
Development Analysis Journal 2, 116.

Rahman, R., Baskoro, D.P.T., Tjahjono, B., 2015. Prospek Pengembangan Komoditas Perkebunan di Wilayah Boliyohuto Kab6upaten Gorontalo. Jurnal Tata Loka 17, 209-222.

Rasyid, A., 2016. Analisis potensi sektor potensi pertanian di Kabupaten Kediri Tahun 2010-2014. Jurnal Ekonomi Pembangunan 14, 100-111.

Ratnasari, E.D., 2014. Sectors analysis and determination of GDP forming leading sector in district Kebumen. Jurnal Fokus Bisnis 13, 1-29.

Rizani, A., 2017. Analisis Potensi Ekonomi di Sektor dan Sub sektor Pertanian, Kehutanan dan Perikanan Kabupaten Jember. Jurnal Ekonomi Pembangunan $15,137-157$.

Rondón-Villarreal, P., López, W.O.C., 2020. Identification of potential natural neuroprotective molecules for Parkinson's disease by using chemoinformatics and molecular docking. Journal of Molecular Graphics and Modelling 97, 107547. https://doi.org/10.1016/j.jmgm.2020.1 07547

Setianto, P., 2014. Komoditas Perkebunan Unggulan yang Berbasis Pada Pengembangan Wilayah Kecamatan di Kabupaten Banjarnegara Provinsi Jawa Tengah. Jurnal Wilayah dan Lingkungan 2, 143-156.

Smales, L.A., 2017. Commodity market volatility in the presence of U.S. and Chinese macroeconomic news. Journal of Commodity Markets 7, 15-27. https://doi.org/10.1016/j.jcomm.2017.0 6.002

Supriyadi, A., Wahyuningsih, S., Awami, S.N., 2014. Analisis pendapatan usahatani kopi (coffea sp) Rakyat di Kecamatan 
Limbang Kabupaten Kendal. Mediagro $10,1-13$.

Tarigan, J.L., Salmiah, Fuiziah, L., 2013. Analisis kelayakan usahatani tembakau rakyat. Journal of Agriculture and Agribusiness Socioeconomics 2, 1-14.

Wang, S., Tan, S., Yang, S., Lin, Q., Zhang, L., 2019. Urban-biased land development policy and the urbanrural income gap: Evidence from Hubei Province, China. Land Use Policy 87, 104066. https://doi.org/10.1016/j.landusepol.20 19.104066

Zakiah, Safrida, Santri, L., 2015. Pemetaan Komoditas Unggulan Sub Sektor
Perkebunan Di Kabupaten Aceh Selatan. Agrisep 16, 35-52.

Zhang, C., Liu, F., Yu, D., 2018. Dynamic jumps in global oil price and its impacts on China's bulk commodities. Energy Economics 70, 297-306. https://doi.org/10.1016/j.eneco.2018.0 1.019

Zhou, Y., Evans, M., Yu, S., Sun, X., Wang, J., 2020. Linkages between policy and business innovation in the development of China's energy performance contracting market. Energy Policy 140, 111208. https://doi.org/10.1016/j.enpol.2019.11 1208 